\title{
OCCUPATIONAL CONTACT ALLERGY TO OMEPRAZOLE AND RANITIDINE
}

\author{
${ }^{1}$ Clinica Creu Blanca, Barcelona, Spain \\ Unit of Allergy \\ ${ }^{2}$ University of Barcelona, Barcelona, Spain \\ Unit of Occupational Medicine, School of Medicine
}

\begin{abstract}
Omeprazole is a proton pump inhibition and ranitidine is an $\mathrm{H} 2$ histamine receptor antagonist widely used in the treatment of gastroesophageal reflex disease, peptic ulcer disease, Zollinger-Ellison syndrome and as a protector of the gastric mucosae. We report a case of occupational contact allergy to omeprazole and ranitidine. A 48-year-old man, with no pre-existing history of atopy or lifestyle factors. He neither had any medical history of consumption of drugs such as ranitidine and omeprazole. He worked for 19 months in the pharmaceutical company that manufactured ranitidine base. He presented rash in the face and eczema on the dorsum of the hands with itching. The study by prick tests with ranitidine gave negative response. Patch testing with ranitidine base and ranitidine hydrochloride gave positive response. A month later, when the patient was asymptomatic he returned to the pharmaceutical company, being switched from this previous job to the reactor manufacturing omeprazole. A few days after that, he presented erythematous eruptions involving face and neck with itching. Prick tests, path tests and in vitro laboratories studies with omeprazole gave positives. In this case the patient presented hypersensitivity type I at omeprazole and hypersensitivity type IV at omeprazole and ranitidine. Our aportation indicates the importance of careful analysis of the occupational exposure histories of patients with the suspected type I or type IV hypersensitivity to allergens, to determine whether work exposure is the cause. Med Pr 2017;68(3):433-435
\end{abstract}

Key words: occupational exposure, occupational contact dermatitis, proton pump inhibitors, ranitidine, omeprazole, active pharmaceutical ingredients

Corresponding author: Pere Sanz-Gallen, University of Barcelona, Unit of Occupational Medicine, School of Medicine, Casanova 143, 08036 Barcelona, Spain, e-mail: 17039psg@comb.cat

Received: June 2, 2016, accepted: December 4, 2016

\section{INTRODUCTION}

Occupational exposure to active pharmaceutical ingredients may cause adverse health effects [1]. Although omeprazole is potentially sensitizing, occupationally acquired cases in pharmaceutical industry are rare [2-6].

We report one case of occupational contact allergy to omeprazole and ranitidine.

\section{CASE REPORT}

A 48-year-old man, with no pre-existing history of atopy or lifestyle risk factors. Neither did he have any medical history of consumption of drugs such as ranitidine and omeprazole. He worked for 19 months in the synthesis of active ingredients for a pharmaceutical company that manufactured ranitidine base. He presented rash in the face and eczema on the dorsum of the hands with itching. Skin symptoms were triggered in the first 4-6 h of starting the workday, and required treatment with corticosteroid topical and anti-histamine oral for resolution. The patient did not develop skin reactions in periods without work activity (weekends and holiday periods).

Prick tests with ranitidine were performed at $30 \mathrm{mg} /$ $\mathrm{ml}$ and $3 \mathrm{mg} / \mathrm{ml}$, and gave negative response.

Patch testing was done according to the GEIDC (Grupo Español de Investigación de Dermatitis de Contacto - the Spanish Contact Dermatitis Research Group) standard series and patch testing - with ranitidine base (5\% pet), ranitidine hydrochloride (1\% pet) and ranitidine hydrochloride (5\% pet). Results were read at $48 \mathrm{~h}$ (day 2) and $96 \mathrm{~h}$ (day 4), which are described in the Table 1 . Prick tests and path tests gave negative results in all 10 healthy controls.

A month later, when the patient was asymptomatic, he returned to the pharmaceutical company, being switched from his previous job to the reactor manufacturing omeprazole. A few days after that, he presented erythematous eruptions involving face and neck with itching. 
Table 1. Patch test of the 48-year-old patient with contact allergy to omeprazole and ranitidine

\begin{tabular}{lcc}
\hline \multirow{2}{*}{ Patch test } & \multicolumn{2}{c}{ Patient's skin } \\
\cline { 2 - 3 } & $\begin{array}{c}\text { after } 48 \mathrm{~h} \\
\text { (day 2) }\end{array}$ & $\begin{array}{c}\text { after } 96 \mathrm{~h} \\
\text { (day 4) }\end{array}$ \\
\hline Ranitidine & ++ & ++ \\
base 0.5\% & ++ & ++ \\
hydrochloride 0.1\% & ++ & ++ \\
hydrochloride 0.5\% & & + \\
Omeprazole & + & ++ \\
$0.1 \%$ & ++ & ++ \\
$0.5 \%$ & ++ & - \\
$1.0 \%$ & - & \\
GEIDC standards series patch & &
\end{tabular}

GEIDC - Grupo Español de Investigación de Dermatitis de Contacto (the Spanish Contact Dermatitis Research Group).

"-" - negative reaction, “+” - weak positive reaction, “++" - strong positive reaction, "+++" - extreme positive reaction.

Prick tests with omeprazole were performed at concentration of $20 \mathrm{mg} / \mathrm{ml}$ and the time of reading was $12 \mathrm{~min}$, obtaining a positive result: papule $6 \times 8 \mathrm{~mm}$, suggesting immediate-type allergy.

In vitro laboratory studies, consisting of a histamine release test by radioimmunoassay, were also performed to support the results obtained through prick testing: this test showed positive results with omeprazole, with a percentage rate of histamine release of $42 \%$ (cut-off value in the test: $30 \%)$.

Omeprazole was patch-tested in saline solution at $0.1 \%, 0.5 \%$ and $1 \%$. Results were read at $48 \mathrm{~h}$ (day 2 ) and $96 \mathrm{~h}$ (day 4), and are described in the Table 1. Prick tests and patch tests gave negative results in 10 healthy controls.

\section{DISCUSSION}

Omeprazole is a proton pump inhibitor. It is administered orally or intravenously, and is widely used in the treatment of gastroesophageal reflex disease, peptic ulcer disease, and Zollinger-Ellison syndrome.

Ghatan et al. (2014) [7] provides a study of 96 workers exposed to omeprazole during manufacturing process for suspected allergy. Twenty-eight workers have positive patch tests. The results of prick tests were all negative. Confino-Cohen and Golberg (2006) [8] proposed a desensitization protocol for omeprazole anaphylaxis.

Ranitidine is an $\mathrm{H} 2$ histamine receptor antagonist, used in the treatment of duodenal ulcers and gastric hypersecretory syndromes. Exposure to ranitidine compounds is an occupational hazard in the pharmaceutical industry and reactions during the drug manufacturing process have been described $[9,10]$.

In this case the patient presented hypersensitivity type I at omeprazole and hypersensitivity type IV at omeprazole and ranitidine. Both omeprazole and ranitidine are low molecular weight substances $(354.42 \mathrm{Da}$ and $350.9 \mathrm{Da}$, respectively), and may therefore trigger allergic pathology mediated by a type I hypersensitivity mechanism. This patient developed type IV hypersensitivity against both omeprazole and ranitidine, but also type I against omeprazole, which has supported the relevance of low molecular weight allergens in the development of allergic disease by different mechanisms.

\section{CONCLUSIONS}

We cannot conclude whether the sensitization to ranitidine and omeprazole in the case of this patient is due to a cross-sensitivity or a co-sensitivity, since no in vitro studies have been carried out by immunoblotting.

Our aportation indicates the importance of careful analysis of the occupational exposure histories of patients with suspected type I or type IV hypersensitivity to allergens, in order to determine whether work exposure is the actual cause.

\section{REFERENCES}

1. Heron RJ, Pickering C. Health effects of exposure to active pharmaceutical ingredients (APIs). Occup Med (Lond). 2003;53(6):357-62, https://doi.org/10.1093/occmed/kqg115.

2. Meding B. Contact allergy to omeprazole. Contact Dermatitis. 1986;15(1):36, https://doi.org/10.1111/j.1600-05 36.1986.tb01259.x.

3. Conde-Salazar L, Blancas Espinosa R, Pérez Hortet C. Occupational airborne contact dermatitis omeprazole. Contact Dermatitis. 2007;56(1):44-6, https://doi.org/10.1111/j.16000536.2007.00921.x.

4. Sanz-Gallen P, Nogué S, Herrera-Mozo I, Delclos G, Valero A. Occupational contact allergy to omeprazole and fluoxetine. Contact Dermatitis. 2011;65(2):118-9, https://doi. org/10.1111/j.1600-0536.2011.01931.x.

5. Alarcon M, Herrera-Mozo I, Nogué S, Sanz-Gallen P. Occupational airborne contact dermatitis from proton pump inhibitors. Curr Allergy Clin Immunol. 2014;27(4):310-3.

6. Yu AM, DeKoven JG. Occupational airborne contact dermatitis from proton pump inhibitors. Dermatitis. 2015; 
26(6):287-90, https://doi.org/10.1097/DER.0000000000 000139.

7. Ghatan PH, Marcusson-Stahl M, Matura M, Björkheden C, Lundborg P, Cederbrant K. Sensitization to omeprazole in the occupational setting. Contact Dermatitis. 2014(6);71:371-5, https://doi.org/10.1111/cod.12305.

8. Confino-Cohen R, Golberg A. Anaphylaxis to omeprazole diagnosis and desensitization protocol. Ann Allergy Asthma Immunol. 2006;96(1):33-6, https://doi.org/10.1016/ S1081-1206(10)61037-X.
9. Romaguera C, Grimalt F, Vilaplana J. Epidemic of occupational contact dermatitis from ranitidine. Contact Dermatitis. 1988;18(3):177-8, https://doi.org/10.1111/j.16000536.1988.tb04512.x.

10. Ryan PJ, Rycroft RJ, Aston IR. Allergic contact dermatitis from occupational exposure to ranitidine hydrochloride. Contact Dermatitis. 2003;48(2):67-8, https://doi.org/10. 1034/j.1600-0536.2003.480202.x.

This work is available in Open Access model and licensed under a Creative Commons Attribution-NonCommercial 3.0 Poland License / Ten utwór jest dostępny w modelu open access na licencji Creative Commons Uznanie autorstwa - Użycie niekomercyjne 3.0 Polska - http://creativecommons.org/ licenses/by-nc/3.0/pl/deed.en. 